\title{
JORGE AMADO EM HQ e o leitor contemporâneo
}

Patrícia Kátia da Costa Pina Ricardo Tupiniquim Ramos

Os quadrinhos, como outras formas minoritárias, são vitais para diversificar nossas percepçôes do mundo.

SCOTT McCLOUD, 2006, p. 19

No fragmento em epígrafe, ao "defender" os quadrinhos em face de artes privilegiadas acadêmica e socialmente, o quadrinista norte-americano Scott McCloud define a marginalidade da $\mathrm{HQ}$ como alternativa para formas artísticas pasteurizadas pelo consumismo contemporâneo. Os quadrinhos, segundo ele, têm propriedades artísticas particulares e relevantes, capazes de dar ao leitor uma experiência estética deleitosa, o que ultrapassa sua tradicional classificação como passatempo inútil e vazio. Os quadrinhos podem encantar os jovens de hoje, tão atraídos pela TV, pelo computador, pelo videogame, por exemplo, para o universo do papel impresso, tornando-os leitores, talvez não leitores do cânone literário, mas de suas adaptaçôes ou de interessantes graphic novels, inserindo-os no ambiente da ficção, da imaginação.

Essa preocupação com a construção de um leitorado jovem significativo não é apenas dos ficcionistas literários. Em livro traduzido e publicado no Brasil em 2008, no qual McCloud ensina a desenhar quadrinhos, sua primeira lição passa pela relação HQ/Leitor. Segundo ele (2008, p. 1-4), todo quadrinista se pergunta como fazer com que os leitores se lembrem de suas obras, como levá-los para dentro da história contada, como fazê-los sentir que estão lá.

No Brasil, no início do século XX, um escritor para adultos se cansa de escrever para "marmanjos" desinteressantes e desinteressados e, em carta a um amigo, afirma que quer escrever livros onde as crianças queiram morar. 
Ando com ideias de entrar por esse caminho: livros para crianças. De escrever para marmanjos já me enjoei. Bichos sem graça. Mas para as crianças, um livro é todo um mundo.

[...] Ainda acabo fazendo livros onde as nossas crianças possam morar. Não ler e jogar fora; sim morar... (LOBATO, 1961, p. 293)

Relacionar criança, jovem e leitura, no Brasil, implica necessariamente recorrer a Monteiro Lobato. Mais que qualquer teórico da literatura e da cultura, Lobato entendeu de discutir e concretizar tudo o que pudesse aproximar a infância e a adolescente do texto literário. No fragmento destacado, retirado de uma de suas cartas a Godofredo Rangel, recolhidas em $A$ barca de Gleyre, ele dá a chave do tamanho da interação entre a arte literária e os pequenos leitores: ela deve ser a casa da criança, seu hábitat privilegiado, deve ser confortável e acolhedora, despertando-lhe a confiança, provocando-lhe prazer, desafiando-a para um crescimento infinito, rumo a estrelas imaginárias, mas nem por isso inalcançáveis, como o pé de feijão daquela história antiga, que conhecemos quando éramos miúdos.

Outro aspecto ressalta do trecho destacado: os pequenos formam um público diferente, escrever para a infância e a adolescência exige do escritor uma preparaçáo específica, que lhe permita configurar simbolicamente um mundo, capaz de interagir com aquele que os pequenos conhecem empiricamente, não para repeti-lo, mas para levá-los a um reconhecimento reflexivo, ou melhor, a um outro conhecimento do já visto e já vivido. Escrever, então, para crianças, sempre vai ter a marca do processo de ensino-aprendizagem.

Este artigo não estuda Monteiro Lobato, mas a adaptação de um romance de um escritor baiano, de grande renome: Jubiabá, de Jorge Amado. Os jovens de hoje são netos e bisnetos daqueles que aprenderam a gostar de ler com as histórias divertidas e irreverentes dos personagens que habitavam as páginas lobatianas e que conheceram a obra amadiana no momento de sua publicação, vivendo a época, experimentando as lutas trabalhistas, as revoluçóes políticas, as transformações sociais. E isso situa esse prazer de ler num não tempo e num não lugar, muito distante das telas de ipad, ipod etc. Nossos meninos e meninas não se identificam mais com a Emília de Lobato, nem com Narizinho e Pedrinho, pois só os conhecem através das diferentes adaptaçôes globais que habitam as telas da TV e as prateleiras das livrarias. E não conhecem a Gabriela de Jorge Amado, mas a da Rede Globo. E a Tieta conhecida também é a do cinema. O mesmo com Teresa Batista. A galeria extensa de personagens amadianas, bem como sua temática social, não é conhecida pelo texto literário, mas por suas adaptações midiáticas.

O bom dessa história é que, para muitos jovens brasileiros, Lobato, Jorge Amado, Machado de Assis, José de Alencar e muitos outros grandes escritores nacionais ainda 
existem graças a essas adaptaçôes. As quadrinizaçóes de suas obras, então, são sucesso garantido de vendas. Os clássicos literários brasileiros e estrangeiros vêm ganhando deliciosas adaptaçóes quadrinísticas, que arrepiam os pesquisadores de literatura, mas divertem crianças e adolescentes, a quem dizem que, no era uma vez da literatura, indivíduos talentosos compuseram obras interessantes, que permanecem vivas, mesmo que com outra roupagem. E essas novas obras velhas podem proporcionar aos leitores, pequenos e grandes, um substancial prazer estético, como afirma McCloud.

Nos últimos anos, mais precisamente nas duas últimas décadas, no Brasil, os PCNs e o PNBE transformaram a HQ (História em Quadrinhos) em instrumento político oficial de formação de leitores (VERGUEIRO, 2009a, p. 11-12). A LDB de 20 de dezembro de 1996 recomenda que o trabalho dos professores de diferentes disciplinas em sala de aula inclua linguagens variadas. Essa preocupação governamental com as competências leitoras do jovem brasileiro responde, na verdade, a uma inquietaçáo que veio dominando os docentes e pesquisadores desde que houve a percepção de que poucos tinham acesso aos bens culturais impressos, e deles usufruíam, e muitos permaneciam excluídos dessa relação de consumo e prazer. Tal constatação acarretou outra: por causa dessa alienação cultural, o país não tinha massa crítica capaz de reagir coletivamente a açôes autoritárias e coercitivas dos direitos individuais.

As questôes concernentes à formação do leitorado brasileiro e à construção simbólica e empírica do gosto pela leitura literária ou não literária ultrapassam as estratégias de letramento escolar e demandam um olhar sobre as condiçóes sociais que cercam os grupos a serem atingidos pelas açóes governamentais ou particulares. Em termos gerais, a preocupação maior gira em torno da educação escolar, da inserção da leitura no currículo, da obrigatoriedade da leitura extraescola etc. Em todas as séries da escolaridade obrigatória, desde que finda o processo de alfabetização, gradativamente os professores e demais gestores escolares percebem que um afastamento entre a criança e o impresso.

Ler quadrinhos é uma boa possibilidade de aproximar a criança e o adolescente de hoje do impresso, quando eles vivenciam o ato de ler como um ato lúdico e prazeroso, uma forma de colocar a afetividade em um lugar de destaque no processo de aquisição das habilidades da leitura e de construção do gosto de ler literatura e outros impressos. A esse respeito, escreve João Marcos Pereira Mendonça:

Uma das características mais conhecidas das histórias em quadrinhos é o seu aspecto ficcional. Pelas características de sua linguagem e talvez pelo caráter de sua produção que, em sua essência, é de baixo custo, as histórias em quadrinhos sempre foram um campo fértil para a criação dos mais diversos, fantasiosos e criativos personagens e histórias. (MENDONÇA, 2009, p. 43) 
A ficcionalidade da HQ joga com duas linguagens, a verbal e a não verbal, hibridizando-as. McCloud (2008, p. 4. Grifo do autor) afirma que "[...] palavras e imagens se combinam para criar efeitos que nenhuma delas poderia criar separadamente". Ao ler quadrinhos, o indivíduo precisa, na maior parte das vezes, conjugar a imagem e a palavra, e a imagem náo se reduz ao desenho da personagem ou da cena, ela engloba do traço demarcador da vinheta até o rabicho do baláo que acolhe a fala. Essa ludicidade da linguagem quadrinística torna os quadrinhos um excelente instrumento de ensino-aprendizagem - e uma fantástica arma de formação do gosto pela leitura, porque amplia o sentido do ato de ler, desvinculando-o da exclusividade da palavra. Mas usar a HQ como mediadora de leitura exige conhecimento da técnica que a preside.

Os quadrinhos não são "coisas" para crianças com pouca competência de leitura nem apenas entretenimento barato. Para Waldomiro Vergueiro e Paulo Ramos, "história em quadrinhos é arte. E ponto final” (2009, p. 7). Como arte, os quadrinhos têm uma linguagem própria, híbrida, que mistura elementos de outras artes, como a literária. Como afirma Paulo Ramos, em A leitura dos quadrinhos:

Quadrinhos são quadrinhos. E, como tais, gozam de uma linguagem autônoma, que usa mecanismos próprios para representar os elementos narrativos. Há muitos pontos comuns com a literatura, evidentemente. Assim como há também com o cinema, o teatro e tantas outras linguagens. (RAMOS, 2009, p. 17)

$\mathrm{Na}$ verdade, os pequenos e os grandes leitores de HQ precisam dominar as estratégias autorais e editoriais para poder interagir com o que leem. McCloud (2008) entende que todos que contam histórias querem que suas narrativas sejam entendidas e que se tornem importantes para o leitor (ou o ouvinte...), daí a necessidade de clareza na ordem narrativa e de uma organização persuasiva do narrado.

Para compor com clareza uma HQ, é preciso fazer a escolha dos momentos que ficarão dentro e dos que ficarão fora da narrativa; é necessário definir a distância e o ângulo com que serão representados os momentos da ação, bem como onde seráo cortados; é importante a determinação do traço com que serão desenhadas as personagens, os objetos etc. Depois disso, o quadrinista deve selecionar as palavras e frases que combinarão com as imagens, agregando a elas informaçôes relevantes.

Os leitores de quadrinhos devem entender a importância das cores, até mesmo se o volume lido estiver em preto e branco. $\mathrm{O}$ rosto das personagens, com suas marcas de emoção, indicadas pelas sobrancelhas e pela boca, é fundamental para a interação com a obra. Portanto, mesmo que se dirijam a crianças, os quadrinhos trazem uma 
complexidade que não minimiza a competência de seu público, antes a amplifica e desenvolve, por causa dos variados estímulos e desafios que propóem.

O objeto de estudo deste artigo é a adaptaçáo literária do romance amadiano Jubiabá. Embora obra novecentista, presa à estética do romance de 30, com uma linguagem próxima ao coloquial e com um tratamento temático acessível a adultos letrados, Jubiabá está longe do universo tecnológico da juventude deste século XXI. O tratamento dado à obra-fonte por Spacca é de imenso valor artístico. Quase todas as páginas vêm repletas de vinhetas que se interpenetram, numa profusão de traços e cores que representam bem a Bahia do início do século XX. As personagens são construídas, em sua maioria, por traços caricaturais, que introjetam um tom bem humorado à $H Q$.

Nas páginas iniciais da adaptação (SPACCA, 2009, p. 6-14), época da infância de Baldo, protagonista do romance-fonte, as vinhetas representam o lado pobre da capital baiana, com suas personagens negras e pobres, amedrontadas com a vida e suas surpresas. As cores predominantes nessas páginas são os tons amarelados e terrosos, os traços são caricaturais e as vinhetas são completamente irregulares, interpenetrandose, com ênfase para os diálogos e pouquíssimos recordatórios. Esse tipo de construção visual cria uma ambientação densa e, pela paleta de cores, sugere a inviabilidade desse mundo, como se ele estivesse preso no limbo da sociedade baiana dos anos iniciais do século XX, onde o preconceito, a miséria e a perseguição policial dominavam a vida dos afro-descendentes em todo o país.

Waldomiro Vergueiro, no texto "Uso das HQS no ensino", ressalta exatamente essa característica da HQ: a junção entre o verbal e o não verbal cria outro código, muito mais instigante que qualquer um dos dois códigos originais por si só. Esse novo nível de comunicação viabilizado pela HQ constrói uma artisticidade peculiar e dá a esse gênero uma forte função social: educar brincando. Segundo esse pesquisador,

[...] a ideia preconcebida de que as histórias em quadrinhos colaboravam para afastar as crianças e jovens da leitura de outros materiais foi refutada por diversos estudos científicos. Hoje em dia sabe-se que, em geral, os leitores de histórias em quadrinhos são também leitores de outros tipos de revistas, de jornais e de livros. Assim, a ampliação da familiaridade com a leitura de histórias em quadrinhos, propiciada por sua aplicação em sala de aula, possibilita que muitos estudantes se abram para os benefícios da leitura, encontrando menor dificuldade para concentrar-se nas leituras com finalidade de estudo. (VERGUEIRO, 2009b, p. 23)

Pela reflexão de Vergueiro, pode-se medir a força social e pedagógica que a HQ tem, desde que usada adequadamente, respeitando-se suas peculiaridades, sua autono- 
mia artística. E é possível, ainda, esboçar uma resposta para outra daquelas questóes arroladas acima: a HQ tem uma natureza que permite multiplicar as competências leitoras de seu público. Dessa forma, um pequeno ou jovem leitor de HQ, como resposta aos estímulos visuais e verbais, desenvolve táticas de interação com outros gêneros, como a literatura, e tem muitas chances de se tornar um "bom leitor", talvez náo um extensivo leitor do cânone literário ocidental, mas, com certeza, um leitor atento a detalhes, aberto a diferentes formas e gêneros textuais, capaz de relacionar variadas linguagens e diferentes suportes.

Jubiabá representa a luta pela sobrevivência do trabalhador negro na Salvador do primeiro novecentos, em meio à intolerância religiosa, à discriminação étnico-racial, à cisão entre o mundo dos ricos e o dos pobres. A adaptação de Spacca usa as cores e os traços para destacar esse universo cruel. Ressaltamos o contraste entre a primeira e a última página da HQ. A primeira traz, no alto da página, uma vinheta em plano geral, mostrando uma luta de boxe no Largo da Sé, Salvador, em 1920. Duas pequenas vinhetas, em plano de detalhe, invadem a vinheta maior e mostram um lutador louro desmaiado. Abaixo da vinheta grande, três vinhetas menores representam a luta entre um lutador negro e aquele lutador louro, que aparecia desmaiado na parte de cima da página. Abaixo, mais três vinhetas mostrando os bastidores da luta, os apostadores, o lutador negro vencido, com o olho direito fechado e inchado. Os balóes estão repletos de onomatopeias, uma das quase vai de uma vinheta a outra. Toda a página dissolve a ordem do narrado e constrói uma temporalidade muito fluida.

A marginalidade da luta representada nessa ordem narrativa visual densa indicia a única via de sobrevivência dos contingentes de negros e brancos excluídos da ordem capitalista e patriarcal que desenhava os contornos da sociedade soteropolitana. E o lutador negro, cuja pior ferida, a mais óbvia na imagem, o impede de ver, é o perdedor. O negro brasileiro, aqui o baiano, historicamente minimizado como indivíduo, sem chances profissionais, não tem, simbolicamente, futuro a ver, seus olhos se turvam diante das injustiças e perdas.

Baldo atravessa todo o romance buscando formas de reagir a essa ordem coercitiva, que, por sua origem africana, denunciada pela cor de sua pele, não lhe daria chance de vitória sobre as intempéries da vida, a menos que, a partir da marginalidade que lhe foi imposta, pudesse usá-la a seu favor. Os bares, as prostitutas, as lutas de boxe, eram seus recursos imediatos. A evolução da imagem de Baldo é gritante. No início da adaptação, a personagem é construída por traços arredondados que enfatizam sua negritude e sua inocência. Jovem, Baldo é magrelo e fracote. Adulto, seu corpo aponta para a vitória sobre a sociedade que o mantinha à margem. 
A última página traz uma única vinheta (2009, p. 84). Mostra Baldo já adulto, musculoso, despedindo-se do navio que parte levando seu amigo Hans, o marinheiro. $\mathrm{O}$ foco da imagem coloca Baldo em tamanho quase igual ao do navio e bem maior que as outras personagens desenhadas. Tanto na primeira como na última página, as cores são quentes, fortes, bem definidas. Tais elementos visuais atraem o olhar do leitor de hoje. A prevalência da imagem sobre a palavra apela para as competências de leitura construídas pela TV, internet etc. As páginas que representam sua infância trazem tons terrosos, como assinalamos anteriormente. Sua adolescência e sua vida adulta sáo representadas por tons fortes, que predominam: vermelho, verde, azul. Mesmo os jovens que não trazem repertórios de leitura representativos do cânone literário brasileiro, mesmo os que náo frequentam museus e não visitam mostras de arte, podem acompanhar a saga do negro Baldo, atribuindo sentido aos fatos narrados, pois as cores e os traços, bem como a arrumação das vinhetas, guiam seu olhar e lhe dão meios de transitar pela narrativa - talvez de morar na história.

Essa adaptação representa muito bem o trabalho artístico da adaptação literária, o processo de recriação e reinvenção da obra-fonte, sua atualização. HQ é uma arte, literatura em quadrinhos é outra arte. Eis o que afirma Lielson Zeni: "As produçōes em quadrinhos baseadas em obras literárias devem ser avaliadas por seu valor como arte autônoma, e não à sombra da produção original”. (ZENI, 2009, p. 127)

Para Iser, por meio da ficção literária, o leitor empírico ${ }^{1}$ pode atravessar as fronteiras do mundo instituído, uma vez que ele o refaz, "antropofagizando" a realidade. Segundo o teórico alemão, o texto ficcional não é pleno em si, carrega lacunas que desenham uma implicitação do leitor imaginado pelo autor e pelos editores, ilustradores etc., porque essa projeçáo tem um forte potencial de provocação.

Parece-nos que as "brechas" textuais que promovem o diálogo da obra com esse leitor "de verdade" constroem uma "representação" de leitor — o leitor implícito — que se quer e que se sabe imprecisa, incompleta, apenas textual, exatamente para gerar sensaçôes e sentimentos surpreendentes no leitor de carne, osso, óculos, levando-o a aproximar-se mais e mais da obra.

$\mathrm{Na}$ adaptação da obra amadiana aqui trabalhada, a construção e a organização das vinhetas nas páginas encenam essas "brechas" textuais e permitem ao leitor empírico interagir com o texto. Na página 23, por exemplo, as vinhetas, em número de sete, representam a fase da vida de Baldo em que ele andava esmolando pelas ruas. Cada vinheta é de um tamanho, todas as imagens, muito coloridas, têm predominância de tons alaranjados e amarelados para as personagens "ricas" e tons cinza, branco, verde escuro e preto para os meninos pobres. As vinhetas podem ser combinadas com certa liberdade e a ligação entre elas abre espaço para a imaginação do leitor. 
A leitura é, sim, uma atividade comandada pelo texto, mas é dependente das possibilidades de interlocução do leitorado histórico que com ele entra em contato:

[...] a relação entre texto e leitor só pode ter êxito mediante a mudança do leitor. Assim o texto constantemente provoca uma multiplicidade de representaçóes do leitor, através da qual a assimetria começa a dar lugar ao campo comum de uma situação. Mas a complexidade da estrutura do texto dificulta a ocupaçáo completa desta situação pelas representaçóes do leitor. $\mathrm{O}$ aumento da dificuldade significa que as representaçóes devem ser abandonadas. Nesta correção, que o texto impõe, da representação mobilizada, forma-se o horizonte de referência da situação. Esta ganha contornos, que permitem ao próprio leitor corrigir suas projeçôes. Só assim ele se torna capaz de experimentar algo que não se encontrava em seu horizonte. (ISER, 1979, p. 88-89)

Essa problematização do leitor empírico, empreendida pela obra em sua própria gênese e em seu processo de interação com o mundo, através da divulgação e da leitura, provoca uma relação texto/leitor que abre incontáveis possibilidades de comunicação, as quais dependem de alguns mecanismos textuais de controle como os vazios, as negaçôes, as supressóes, as cesuras, as imagens, os cerzidos do texto, enfim, todos construindo o lugar do leitor "de verdade", através dessa implicitação de um leitor desejado pelos autores e editores, quebrando o fluxo textual, interrompendo a articulação discursiva sequencial. Dessa forma, o texto pode provocar o imaginário de seu interlocutor, dinamizando o impresso, por meio de elementos capazes de suscitar uma "leitura ativa".

Refletir, assim, acerca das relaçôes entre o texto ficcional e o leitor empírico permite pensar que a tensão que o preside é que funcionaria como instrumento de provocação e de "sedução" dos interlocutores textuais, transformando-os a partir da interaçáo com o lido. Tal tensão própria do jogo ficcional remete às estratégias textuais de implicitação do leitor - e de provocação de sua face empírica — , bem como de condução da leitura, discutidas por Iser.

Essa ludicidade da linguagem ficcional abriria caminho para que o leitor, histórica e socialmente localizado, interagisse com o texto. E pensamos que a ludicidade da linguagem quadrinística também faz isso e, talvez, de modo mais eficaz, por ser uma linguagem híbrida, que mescla recursos verbais e nãoverbais, brincando com os mais diferentes sentidos daquele que joga com ela.

As ferramentas narrativas quadrinísticas correspondem a outras tantas ferramentas literárias, mas não nascem destas, nem delas dependem. As relaçóes entre os quadrinistas e seu público divergem tanto das relaçóes entre o diretor e o roteirista da TV e do cinema com os espectadores, como das relaçóes entre o poeta e o ficcionista e seus 
leitores. No caso do cinema e da TV, a estaticidade da imagem quadrinística pode criar maior intimidade com o leitor. No caso da literatura, a costura das vinhetas, as cores, as formas, estabelecem uma interação visual com o impresso, requisitando do leitor o uso de muitas habilidades no ato da leitura, o que pode atender à inquietaçáo da juventude contemporânea.

Podemos afirmar, assim, que não há neutralidade no ato da leitura — ler é uma travessia das múltiplas textualidades inscritas na palavra/imagem impressa. E atravessá-las significa pôr em diálogo os repertórios previstos no texto/obra e os repertórios pertinentes a cada leitor empírico - ou seja, ler pode ser entendido como um dos jogos possíveis na sociedade. No ato da leitura, entramos sozinhos no texto e saímos dele modificados, mesmo quando a leitura é coletiva, pois cada um joga com a sua individualidade, ainda que de acordo com regras gerais. E melhor, cada um joga porque quer jogar.

Pode-se deduzir daí que o ato de ler é um ato de liberdade, o que é confirmado por Bordini e Aguiar: "A riqueza polissêmica da literatura é um campo de plena liberdade para o leitor..." (BORDINI e AGUIAR, 1988, p. 15) Ao deparar-se com uma obra impressa, o indivíduo póe em diálogo as contingências que cercam seu cotidiano e o mundo do texto, abrindo seu imaginário para as vivências outras que lhe sáo apresentadas a cada página.

O processo da leitura não é uma via de mão única, porque não se trata apenas do texto que invade o leitor, já que este também se insinua por entre palavras e imagens, efetuando uma pessoalização do objeto lido. Ler implica interpretar e criticar. As associaçôes que estabelecemos ao ler nos revelam quem somos no e a partir do texto lido. $\mathrm{O}$ ato da leitura, portanto, não se constrói por um mero processo de decodificação do impresso, pois esse trânsito entre texto e leitor está situado histórica, cultural, politicamente, envolvendo, ainda, condicionamentos menores, de ordem psicológica, social, econômica, enfim.

Ao compreender-se interagindo com o texto, o leitor empírico se percebe numa intimidade antes não imaginada, intimidade esta que pode levá-lo a querer repetir a experiência e a gostar do desafio. As estratégias de escrita e publicaçáo aqui descritas balizam o processo de leitura, ainda que não o constranjam, mas direcionam possíveis apropriaçôes, tanto por parte de leitores com vasto repertório quanto por parte dos neófitos das letras impressas.

As adaptaçôes constituem apropriaçôes que cristalizam determinadas formas de interação do escritor/editor com o texto-fonte. Isso significa que as adaptaçôes trazem sentidos e valores agregados ao texto original, os quais o atualizam e transformam-no em um novo texto. Sobre isso, observa Lielson Zeni: 
A adaptação é uma leitura que se transpóe em releitura e, com essa releitura, alguns elementos estruturadores do texto de origem ganham destaque e, por consequência, reapresentam a estrutura do texto original e sua relação com o conteúdo e com a forma, trazendo uma nova, porém não definitiva, leitura para a obra original. (ZENI, 2009, p. 141)

O adaptador é uma espécie de consumidor primeiro do texto e, como afirma Martín-Barbero, em Dos meios às mediaçóes (MARTÍN-BARBERO, 2003, p. 302), o consumo é o lugar de uma luta que implica mais que a posse do objeto, implica seus usos sociais e as competências culturais com que objeto e consumidor interagem. $\mathrm{O}$ consumo é objeto de discursos/atos de poder...

"Toda interpretación transforma algo en otra cosa" (ISER, 2005, p. 29). As histórias em quadrinhos que se apropriam de obras literárias promovem certo direcionamento do ato de ler, como apontamos acima, exatamente porque concretizam, no papel impresso, uma leitura já feita. E, é claro, transformam o texto-fonte em outro texto. Mas, também, permitem que os leitores, que ainda não têm um grande repertório a ser posto em ação no ato da leitura, se identifiquem mais intensamente com as personagens e suas ações, com a trama e suas ideias.

As obras-fonte apresentam aos jovens leitores contemporâneos uma série de obstáculos que os quadrinhos relativizam. A representação visual é uma alternativa muito interessante nesse sentido. Como esclarece Martine Joly:

Seja ela expressiva ou comunicativa, é possível admitir que uma imagem sempre constitui uma mensagem para o outro, mesmo quando esse outro somos nós mesmos. Por isso, uma das precauçóes necessárias para compreender da melhor forma possível uma mensagem visual é buscar para quem ela foi produzida. (JOLY, 1996, p. 55)

Para quem a adaptação da obra amadiana para HQ foi criada? É claro que, pela relação com a obra-fonte, escrita e publicada para o leitor adulto novecentista, essa adaptação dirige-se a um público, no mínimo, adolescente, mas nada impede que leitores especializados possam fruir essa adaptação.

No entanto, o leitor desejado pelas editoras, a "fatia do mercado" que elas pretendem alcançar, corresponde aos jovens, que, nas escolas, devem ser preparados para que se tornem leitores dos grandes clássicos da literatura brasileira e universal. $\mathrm{O}$ interessante é que nesse jogo de construção simbólica e empírica do gosto pela leitura e de hábitos de consumo do impresso, essa adaptação propóe uma nova obra e viabiliza novas formas de se pensar e ler literatura. 
O leitor que lê os quadrinhos toma conhecimento de uma história adaptada, ou seja, ele é conduzido pelo olhar de uma alteridade que se revela, que se faz presente desde a apresentaçáo do volume de HQ. Esse leitor sabe que náo está lendo o texto de Jorge Amado, mas, sim, uma outra forma de apresentação desse texto, ou seja, uma nova e diferente obra. E o professor precisa mostrar isso ao aluno. É necessário explorar, em sala de aula, as peculiaridades da linguagem quadrinhística, estudar as cores, os balóes, as vinhetas, tanto quanto o texto verbal. E o mais importante: é preciso enfocar a intersecção entre o verbal e o não verbal.

A leitura não pode continuar sendo vista como uma atividade disciplinar - ela é inter e transdisciplinar. Por isso não queremos reduzir a definição de leitura à leitura literária, nem a de leitor à de leitor literário. Ler HQ também é ler. E é ler uma obra artística. A leitura é a atividade intelectual e emocional de relacionar percepçóes, conceitos e sensaçôes, a partir da interação de um sujeito com uma textualidade. Tanto o sujeito (leitor) como o texto são históricos e culturais, isto é, carregam características que denunciam suas origens, expectativas e preferências. A interlocução entre ambos é transformadora. E isso, embora possa ser bastante lúdico e prazeroso no âmbito literário, não ocorre apenas dessa forma.

Como prática do intelecto, plena de emoçóes, a leitura é social e cultural. J. Camelo Ponte mostra essa relação entre texto-indivíduo-sociedade como fundamental (2007, p. 42):

A leitura é [...] uma atividade cultural do homem que, apesar das mudanças do instrumental necessário para que ela possa ser feita, estará sempre presente na vida dos indivíduos tanto para a construção e reconstrução individual do ser humano quanto para o desenvolvimento e reestruturação da sociedade.

Para Ponte, a transformação operada pela leitura, que também vai atrelada à palavra, já incluindo sutilmente a previsão de outros suportes que não o livro, é uma transformação particular e coletiva. Segundo esse pesquisador, os atos de leitura exigem e suscitam polissemias que podem provocar visóes de mundo transitórias e críticas. A leitura, como a entende Ponte (2007, p. 24), depende das mudanças tecnológicas e não aceita, hoje, ser resumida a uma literariedade de estranhamento artístico. Não é mais apenas a diferença da palavra literária que transforma o leitor: as mídias, os suportes, os outros textos que testam os limites da arte da palavra interferem nesse processo.

$\mathrm{O}$ jogo instaurado pelos quadrinhos pode convidar o leitor do século XXI a sair do circuito da visualidade e a entrar no campo da palavra, da imagem verbal. Ou melhor: pode fazê-lo conjugar, numa diferente experiência de percepção, o visual e o verbal 
(daí, reiteramos, a linguagem dos quadrinhos ter um caráter híbrido), aproximando o impresso das mídias com as quais esse consumidor já está habituado em seu cotidiano. E a própria visualidade pode permitir-lhe reinventar o lido e reinventar-se a partir do lido.

D. Jota Carvalho, em A educação está no gibi, afirma:

Seja pela atraente mistura de texto e desenho, seja pelos diversos tipos de histórias ou, ainda, por heróis (e super-heróis) inesquecíveis, os quadrinhos sempre foram uma mídia sedutora para o público infantojuvenil. Assim, naturalmente, as HQs são também um instrumento potencial para educar. (CARVALHO, 2006, p. 31)

A adaptação criada por Spacca não traz exatamente um super-herói, mas coloca como centro das atençôes e como direcionador explícito da leitura a imagem de Baldo como um trabalhador forte fisicamente e poderoso socialmente, apesar de pobre. A adaptação dá a Baldo um poder simbólico visível, principalmente na última página, quando sua máo está quase do tamanho do navio - Baldo ocupa o primeiro plano da vinheta, como passa a ocupar na Salvador do início do século XX.

Em sua forma original, a obra amadiana não tem instrumentos para chegar aos jovens de hoje, ainda que trate de temas atuais, como a discriminação racial, a miséria, o desrespeito pelo trabalhador. Esses novos leitores têm assim suas habilidades de leitura e de consumo de bens culturais forjadas por essas novas mídias. Por si só, as obras clássicas encontrarão muitos obstáculos para interagir com o leitorado juvenil brasileiro contemporâneo. Elas não têm artifícios que possam "matar" a fome de saber e lazer do jovem contemporâneo.

$\mathrm{Na}$ adaptação do romance de Jorge Amado para quadrinhos, Spacca e os editores introjetaram em cada página uma representação daquele que consideram ser o leitor contemporâneo, jogando com suas expectativas e com seu repertório em construção, através da criaçáo dos quadros e da organização do material verbal. A leitura desse volume de HQ nos parece estabelecer um saudável confronto entre a literatura, os seus diferentes suportes e o leitorado de agora, imerso num mundo que transita entre a concretude do impresso e a virtualidade da internet.

As novas mídias, dentre as quais a TV, o cinema, os quadrinhos, entram no circuito da formação do gosto pela leitura literária construindo um espaço paradoxal, mas eficiente. Os quadrinhos invadem os leitores e deixam-se invadir por eles, estabelecendo caminhos alternativos, lúdicos, de ler a ficção, o mundo e a si mesmo no mundo. Entendemos que as tessituras textuais, ou seja, as várias materialidades dos múltiplos textos que habitam nosso dia a dia, são fundamentais. Aquele que cria o texto introjeta neste, 
voluntária ou involuntariamente, seus valores, suas visóes do mundo, suas perspectivas históricas, filosóficas, religiosas, as quais se concretizam quer na seleção temática, quer na escolha vocabular, quer na combinaçáo das cores, quer no limite dos traços, quer no foco da câmera, quer na melodia da música, quer na forma das roupas ou no tipo de maquiagem, ou na escolha dos vidros de um prédio ou das flores no jardim de uma praça.

As formas de ler mudaram, porque nossas formas de relacionamento mudaram também. Isso é histórico e cultural. Ninguém mais leva sete anos namorando, Jacó nenhum serve a Labão para receber $\mathrm{Raquel}^{2}$, permanecendo fiel, apesar das armadilhas. Se o amor é rápido e fragmentado, a leitura, paixão entre o leitor e o texto, também. $\mathrm{O}$ leitor, hoje, é um ser em processo de fragmentação: ele precisa viver inúmeros papéis num só dia e esse modo de encenar-se a si mesmo acaba se tornando uma forma de repúdio a uma possível essencialidade. Para esse leitor que se nega como ser integral, que se constrói como quebra-cabeças em permanente incompletude, não pode haver um texto a ser lido, a palavra não é o único objeto de leitura.

Assim, entendemos que as adaptaçôes dos clássicos para HQ podem, sim, entrar com grandes vantagens no infinito jogo da formação do gosto pela leitura literária e não literária na contemporaneidade, acercando-se não apenas dos jovens leitores, mas viabilizando a interação com diferentes segmentos etários e sociais do potencial leitorado brasileiro. E isso não por serem portas para os clássicos, mas novas e instigantes leituras dos clássicos, atualizando-os, trazendo-os para o mundo dos malnascidos, bemnascidos, quase-nascidos e quase-moribundos, consumidores das novas tecnologias, com padrôes de gosto que privilegiam a interação entre múltilpos códigos, diferentes suportes, variadas linguagens.

\section{$\operatorname{son}$}

NOTAS

1 Entendo por leitor empírico o leitor de carne e osso, isto é, todos nós que interagimos com um texto impresso. Esse leitor empírico, no ato da leitura, é chamado ao texto pelo leitor implícito (Iser), ou seja, pelas estratégias narrativas autorais que guiam o leitor "de verdade" pelas sendas da obra.

2 Poema de Camóes: "Sete anos de pastor Jacó servia /Labão, pai de Raquel, serrana bela;/Mas não servia ao pai, servia a ela,/E a ela só por prêmio pretendia/Os dias, na esperança de um só dia,/Passava, contendo-se com vê-la;/Porém o pai, usando de cautela,/Em lugar de Raquel lhe dava Lia/Vendo o triste pastor que com enganos/ Lhe fora assim negada a sua pastora, /Como se a não tivera merecida,/ Começa de servir outros sete anos,/Dizendo - mais servira, se não fora/Para táo longo amor táo curta a vida!”. A referência aponta para o imediatismo e pragmatismo contemporâneos. 


\section{REFERENNCIAS}

AGUIAR, Vera Teixeira de. Da teoria à prática: competências de leitura. In: MARTHA, Alice Áurea Penteado (Org.). Leitor, leitura e literatura: teoria, pesquisa e prática - conexôes. Maringá: EdUEM, 2008.p. 13-26.

BORDINI, Maria da Glória e AGUIAR, Vera Teixeira de. Literatura: a formação do leitor. Porto Alegre: Mercado Aberto, 1988.

CARVALHO, D Jota. A educação está no gibi. Campinas: Papirus, 2006.

COSTA, Marta Morais. Sempreviva: a leitura. Curitiba: Aymará, 2009.

HUIZINGA, Johan. Homo ludens: o jogo como elemento da cultura. Tradução de João Paulo Monteiro. São Paulo: Perspectiva, 2001.

ISER, Wolfgang. A interação do texto com o leitor. In: LIMA, Luiz Costa (Org.). A literatura e o leitor: textos de estética da recepção. Seleção, Tradução e introdução de Luiz Costa Lima. Rio de Janeiro: Paz e Terra, 1979, p. 83-132.

. Rutas de la interpretación. Traducción de Ricardo Rubio Ruiz. México: FCE, 2005.

JOLY, Martine. Introdução à análise da imagem. Tradução de Marina Appenzeller. Campinas/São Paulo: Papirus, 1996.

LOBATO, Monteiro. A barca de Gleyre. 10. ed. São Paulo: Brasiliense, 1961. $2^{\circ}$ tomo.

MARTÍN-BARBERO, Jesús. Dos meios às mediaçôes: comunicaçáo, cultura e hegemonia. Rio de Janeiro: Editora UFRJ, 2003.

McCLOUD, Scott. Desenhando quadrinhos. Tradução de Roger Maioli dos Santos. São Paulo: M. Books do Brasil Editora Ltda., 2008.

Reinventando os quadrinhos. Traduçáo de Roger Maioli dos Santos. São Paulo: M. Books do Brasil Editora Ltda., 2006.

MENDONÇA, João Marcos Pereira. Biografias em Quadrinhos. In: VERGUEIRO, Waldomiro e RAMOS, Paulo (Orgs.). Quadrinhos na educação: da rejeição à prática. São Paulo: Contexto, 2009b, p. 41-72.

PONTE, J. Camelo. Leitura: identidade \& inserção social. São Paulo: Paulus, 2007.

RAMOS, Paulo. A leitura dos quadrinhos. São Paulo: Contexto, 2009.

SPACCA. Jubiabá de Jorge Amado. São Paulo: Companhia das Letras, 2009.

VERGUEIRO, Waldomiro e RAMOS, Paulo (Orgs.). Muito além dos quadrinhos: análises e reflexóes sobre a 9a arte. São Paulo: Contexto, 2009a.

. Quadrinhos na educação: da rejeição à prática. São Paulo: Contexto, 2009b.

ZENI, Lielson. Literatura em quadrinhos. In: VERGUEIRO, Waldomiro e RAMOS, Paulo (Orgs.). Quadrinhos na educação: da rejeiçâo à prática. São Paulo: Contexto, 2009b, p. 127-165.

\section{Resumo}

Este artigo discute alguns dos desafios que cercam a leitura de literatura, efetuada por crianças e jovens, na contemporaneidade, em face das novas, diferentes e sedutoras mídias que nos cercam, tendo como objeto de estudo a narrativa amadiana Jubiabá, em HQ. Preocupam-nos o lugar que o texto literário ocupa no cotidiano de jovens e adultos hoje, bem como as estratégias autorais e/ ou editoriais para torná-lo prazeroso e competitivo, em relação aos games, à TV, ao cinema etc. O objetivo é investigar como a leitura do texto literário, publicado em outra mídia que não o livro, 
enfatiza o lúdico, podendo funcionar como forma de apreensão do mundo e construção simbólica de identidades. Para tanto, discutir-se-ão as teorias de Iser, bem como as afirmaçóes de Ramos, Vergueiro, entre outros, no sentido de se definir o ato da leitura como ação lúdica, como jogo, que envolve uma interação autor/editor-texto/imagem-leitor e que prevê inúmeras possibilidades de mediação.

Palavras-chave: Leitura; Jorge Amado; HQ; Leitor.

\section{Abstract}

This article discusses some challenges faced by the act of reading literature by children and teenagers, in the advent of seducing and varied new media. The object of study is Jorge Amado'sJubiabá, in both versions, literary and comic strips. What interests me is the place occupied by literary text in teenagers' and adults' daily life, as well as the strategies of authors and/or publishers to make them pleasant and appealing when compared to games, TV, movies, etc. My objective is to investigate how the reading of literary text published in a media other than the book emphasizes the act of playing, being able to function as means to apprehend the world and as tool to build symbolic identity. I am going to discuss Iser's theories as well as Ramos's, Vergueiro's among others, trying to define the act of reading as playful act, as game which involves an interaction between author/publisher-text/ imago-reader with a great number of possible mediation.

Key words: Reading; Jorge Amado; Comic strips; Reader.

Patrícia Kátia da Costa Pina é graduada em Letras pela Universidade Santa Úrsula, Mestra em Literatura Brasileira e Doutora em Literatura Comparada pela UERJ. É Professora Titular de Literatura Brasileira da UNEB, Campus II, Caetité-Ba, onde atua como Professora Permanente do Mestrado em Crítica Cultural.

Ricardo Tupiniquim Ramos é licenciado em Letras pela UCSAL, Mestre e Doutor pela UFBA. É Professor Assistente da UNEB. Desenvolve e orienta pesquisas em educação. Sócio do Círculo Fluminense de Estudos Filológicos (CiFEFiL) e pesquisador associado à Cátedra UNESCO de Leitura. 